\title{
A systematic review of the comparison of the incidence of seeding metastasis between endoscopic biliary drainage and percutaneous transhepatic biliary drainage for resectable malignant biliary obstruction
}

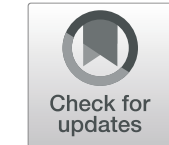

\author{
Lei Wang ${ }^{1,2 \dagger}$, Nanping Lin ${ }^{1,2+}$, Fuli Xin ${ }^{1,2+}$, Qiao Ke ${ }^{1,2}$, Yongyi Zeng ${ }^{2,3,4,5^{*}}$ and Jingfeng Liu ${ }^{1,2,3,4}$
}

\begin{abstract}
Background and aim: Endoscopic biliary drainage (EBD) and percutaneous biliary drainage (PTBD) are the two main strategies of preoperative biliary drainage (PBD) for resectable malignant biliary obstruction (MBO) worldwide, but which is better remains unclear. Seeding metastasis (SM) has been reported repeatedly in the recent decade, although it is rarely taken into consideration in the choice of PBD. Hence, a systematic review was badly warranted to evaluate the incidence of SM between PTBD and EBD in the preoperative treatment of MBO.

Methods: PubMed, MEDLINE, the Cochrane Library, and Web of Science were used to identify any potentially eligible studies comparing the incidence of SM between EBD and PTBD from Nov 1990 to Mar 2018. The effect size was determined by odds ratio (OR) with 95\% confidence interval (Cl).

Results: Ten studies were enrolled in this study, including 1379 cases in the EBD group and 1085 cases in the PTBD group. Results showed that the incidence of SM in the EBD group was significantly lower than that in the PTBD group ( $10.5 \%$ vs. $22.0 \%, \mathrm{OR}=0.35,95 \% \mathrm{Cl} 0.23 \sim 0.53)$. Subgroup analysis stratified by the definition of SM showed that the pooled ORs for peritoneal metastasis and tube-related SM between EBD and PTBD were 0.42 ( $95 \% \mathrm{Cl} 0.31 \sim 0.57$ ) and 0.17 (95\% Cl 0.10 0.29), respectively. Subgroup analysis stratified by the location of MBO showed that the pooled ORs for the incidence of SM between EBD and PTBD for perihilar cholangiocarcinoma, distal cholangiocarcinoma, and pancreatic cancer were 0.27 (95\% Cl 0.13 0.56), 0.32 (95\% Cl 0.17 0.60), and 0.27 (95\% Cl 0.19 0.40), respectively.

Conclusion: $\mathrm{EBD}$ should be the optimal PBD for MBO considering the SM, but it deserved further validation.

Keywords: Preoperative biliary drainage, Malignant biliary obstruction, Percutaneous biliary drainage, Endoscope biliary drainage, Seeding metastasis, Meta-analysis
\end{abstract}

\section{Introduction}

Patients diagnosed with perihilar cholangiocarcinoma (PHC), distal cholangiocarcinoma (DCC), and pancreatic cancer (PC) typically present with malignant biliary obstruction $(\mathrm{MBO})$, which is one of the crucial reasons for

\footnotetext{
* Correspondence: lamp197311@126.com

'Lei Wang, Nanping Lin and Fuli Xin contributed equally to this work.

${ }^{2}$ The Liver Center of Fujian Province, Fujian Medical University, Fuzhou 350025, Fujian, People's Republic of China

${ }^{3}$ The First Clinical Medical College of Fujian Medical University, Fuzhou 350005, Fujian, People's Republic of China

Full list of author information is available at the end of the article
}

the failure of surgery [1]. Preoperative biliary drainage $(\mathrm{PBD})$ is deemed to improve jaundice before surgery and decrease postoperative morbidity and mortality, although it remains controversial [2-4]. Furthermore, either percutaneous transhepatic biliary drainage (PTBD) or endoscopic biliary drainage (EBD) is the best strategy for resectable $\mathrm{MBO}$ is also a question [5-9].

Seeding metastasis (SM) is rarely refereed worldwide, but it has been reported frequently in Japan [10-17]. The incidence of SM in Japan was reported to range from 4.0 to $40.4 \%$ [10-17], which is no longer an "unusual"

(c) The Author(s). 2019 Open Access This article is distributed under the terms of the Creative Commons Attribution 4.0 International License (http://creativecommons.org/licenses/by/4.0/), which permits unrestricted use, distribution, and reproduction in any medium, provided you give appropriate credit to the original author(s) and the source, provide a link to the Creative Commons license, and indicate if changes were made. The Creative Commons Public Domain Dedication waiver (http://creativecommons.org/publicdomain/zero/1.0/) applies to the data made available in this article, unless otherwise stated. 
contingency. EBD was reported repeatedly to superior to PTBD in the prophylaxis of SM [10-17], but it was contradicted by a multicenter, retrospective study derived from US-Euro [18]. Hence, a systematic review is warranted to evaluate the incidence of SM between EBD and $\mathrm{PTBD}$ in the procedure of PBD for patients with $\mathrm{MBO}$.

\section{Materials and methods}

\section{Literature search}

A comprehensive search was conducted by two independent researchers to clarify all published researches of PBD for preoperative obstructive jaundice. English electronic databases such as PubMed, MEDLINE, the Cochrane Library, and Web of Science were used to seek the literature, from Nov 1990 to Mar 2018. Keywords including "preoperative biliary drainage" and "malignant biliary obstruction" combined with free text words such as "percutaneous transhepatic biliary drainage" or "endoscopic biliary drainage" or "seeding metastasis" appeared in the electronic search.

\section{Selection criteria}

Inclusion criteria are as follows: (1) cohort studies and randomized controlled trials were both considered, (2) PBD either PTBD or EBD for patients with MBO, (3) the primary endpoint was SM, and (4) sufficient data such as the baseline of characteristic were depicted.

Exclusion criteria are as follows: (1) in vitro or animal studies; (2) case reports, letters, reviews, and conference reports; (3) studies based on overlapping cohorts derived from the same center; and (4) sample size was not more than 20 .

In case of results reported from the same center more than once, the latest was extracted.

\section{Data extraction}

Predefined forms including baseline characteristics and outcomes were extracted from each study by Nanping Lin and Fuli Xin independently and then assessed by Lei Wang, Nanping Lin, and Fuli Xin. In the case of disagreement, a third investigator intervened for a conclusion.

\section{Intervention and outcome definition}

PTBD (percutaneous transhepatic biliary drainage), including external drainage and internal drainage (percutaneous transhepatic biliary stent, PTBS), is depicted in Table 2.

EBD (endoscopic biliary drainage), including external drainage such as endoscopic nasobiliary drainage (ENBD) and internal drainage (endoscopic biliary stent, EBS), is also depicted in Table 2.
The mean interval between surgery and onset of the recurrence (SM) is depicted in Table 1.

SM was extracted directly from the original studies and was different from each other. The types of SM were as follows: (1) PTBD catheter tract recurrence, (2) pleural dissemination on the right side alone, (3) peritoneal dissemination, and (4) intrahepatic metastasis (only for PC) $[10,14]$.

When it was hard to distinguish tube-related SM with peritoneal metastasis, data was merged and subgroup analysis was avoided.

\section{Quality assessment}

Considering all of the studies were retrospective cohort studies, quality assessment was assessed by the NewcastleOttawa Scale (NOS). Studies scored as $\geq 6$ were considered of high quality.

\section{Statistical analysis}

The systematic review was registered at http://www.crd. york.ac.uk (122086) and performed using RevMan version 5.3 and Stata 14. Considering the apparent heterogeneity among different studies, such as different strategies of PBD, the stent material of biliary drainage, and the severity of obstructive jaundice, the random-effects model was used to compare the incidence of seeding metastasis between PTBD and EBD [20]. Odds ratios (ORs) were for the dichotomous outcomes, followed with $95 \%$ confidence intervals (CI). Publication bias was evaluated by visually assessing the asymmetry of an inverted funnel plot and then was supported quantitatively by Egger's tests.

\section{Results}

Base characteristic of the included studies

Initially, 106 reports were identified by two independent reviewers. Twelve articles were excluded after duplicate removal by NoteExpress 3.1. After browsing titles and abstracts, 83 records were excluded. Among the remaining 11 articles, one record was excluded for lack of enough cases. Finally, 10 reports remained, including 6 studies of PHC [10,12, 15, 16, 18, 19], 2 of DCC, and 2 of PC $[11,14]$. In total, 2464 patients were enrolled in this meta-analysis, with 1379 cases in the EBD group and 1085 cases in the PTBD group (Fig. 1).

The characteristic and quality of the included trials are shown in Table 1. All the studies included in this metaanalysis were nonrandomized studies and were assessed by NOS. The scores ranged from 6 to 9 , which indicated that all the studies were of high quality (Table 2).

\section{Comparison of SM incidence between EBD and PTBD for resectable MBO}

SM was reported in all the included studies [10-19], and results showed that there were significant differences in the 


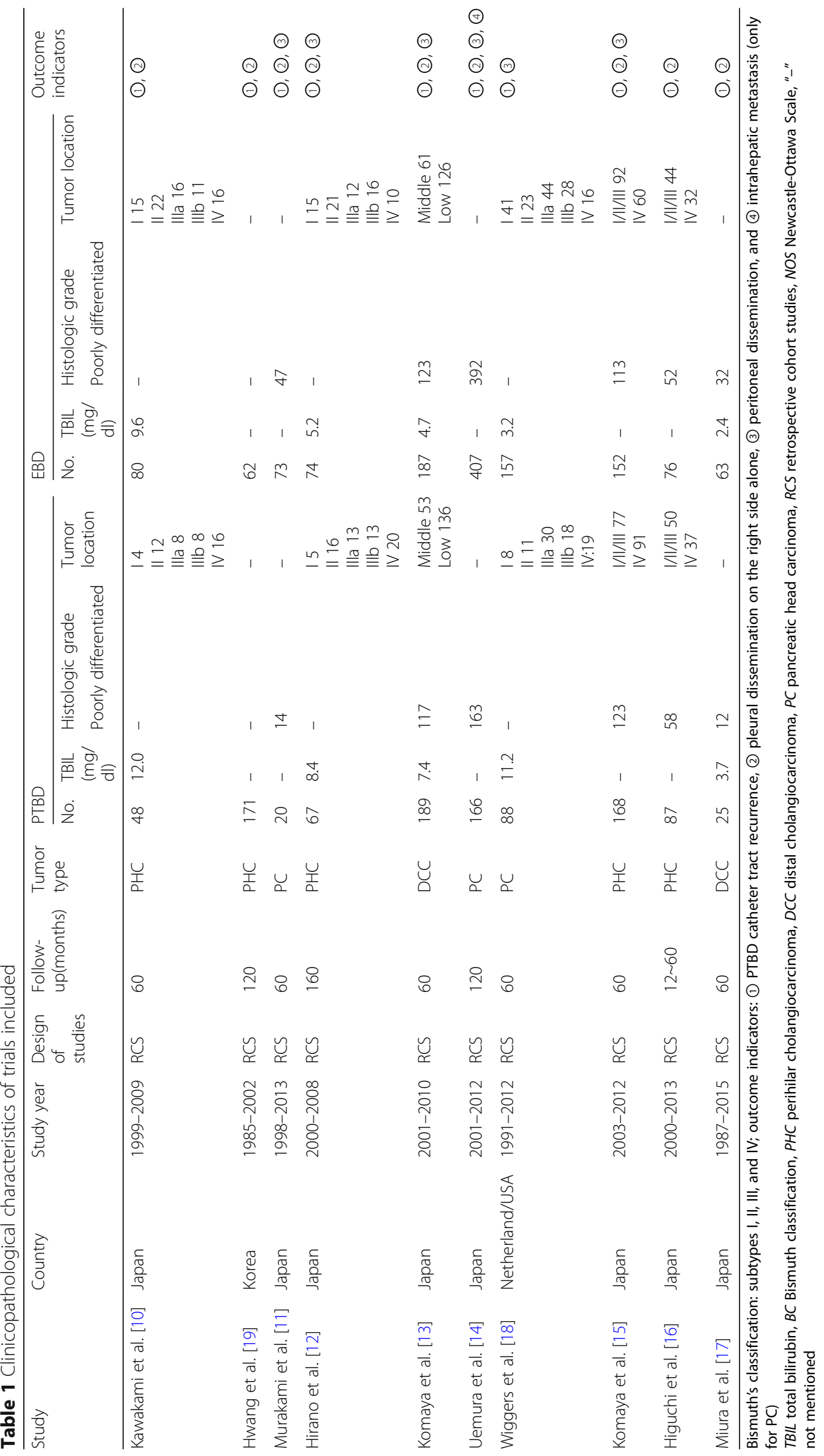


rates of seeding metastasis between EBD and PTBD (10.5\% vs. $22.0 \%, \mathrm{OR}=0.35,95 \% \mathrm{CI} 0.23 \sim 0.53, P<0.001$, Fig. 2 ).

\section{Subgroup analysis of different SM incidences between EBD and PTBD for resectable MBO}

SM was divided into peritoneal metastasis and tuberelated seeding metastasis, and subgroup results showed that EBD was superior to PTBD both in peritoneal metastasis $[11-15,17,18](10.0 \%$ vs. $20.2 \%$, OR $=0.42,95 \%$ CI $0.31 \sim 0.57, P<0.001$, Fig. 3(a)) and tube-related SM $[10,12-15,17-19](2.0 \%$ vs. $6.7 \%, \mathrm{OR}=0.17,95 \% \mathrm{CI}$ $0.10 \sim 0.29, P<0.001$, Fig. 3(b)).

\section{Subgroup analysis of SM incidences between EBD and PTBD for different MBO}

PHC, DCC, and PC were the mainly pathogenies for $\mathrm{MBO}$, and subgroup results showed that, in the prevention of SM, EBD was superior to PTBD in PHC $[10,12,15,16,18,19](7.8 \%$ vs. $17.1 \%, \mathrm{OR}=0.27$, 95\% CI 0.13 0.56, $P<0.001$, Fig. 4(a)), DCC $[13,17]$ (6\% vs. $18.2 \%, \mathrm{OR}=0.32,95 \%$ CI $0.17 \sim 0.60, P<$ 0.001, Fig. 4(b)), and PC [11, 14] (15.6\% vs. 40.3\%, $\mathrm{OR}=0.27,95 \%$ CI 0.19 0.40, $P<0.001$, Fig. 4(c)).

\section{Publication bias}

Funnel plot and Egger's tests were used to detect the publication bias of our meta-analysis. A total of 10 studies [10-19] evaluating the seeding metastasis rate of MBO patients treated with EBD or PTBD exhibited a basically symmetrical funnel plot (Fig. 5a) and yielded an Egger's test score of $P=0.409$ (Fig. 5b).

\section{Discussion}

This is the first systematic review focusing on the incidence of SM related to PBD for resectable MBO. A total of 10 studies with 2230 patients comparing the incidence of SM between PTBD and EBD were included in this study. Meta-analysis showed that EBD was associated with fewer SM than PTBD in the procedure of PBD for resectable $\mathrm{MBO}(10.5 \%$ vs. $22.0 \%, P<0.00001)$. Hence, we concluded that EBD could be considered in patients with resectable $\mathrm{MBO}$.

PHC, DCC, and PC are typically present with biliary obstruction, which often increases the risk of perioperative mortality and morbidity [21, 22]. Palliative biliary drainage has been repeatedly confirmed to be efficient in the improvement of prognosis for patients with unresectable

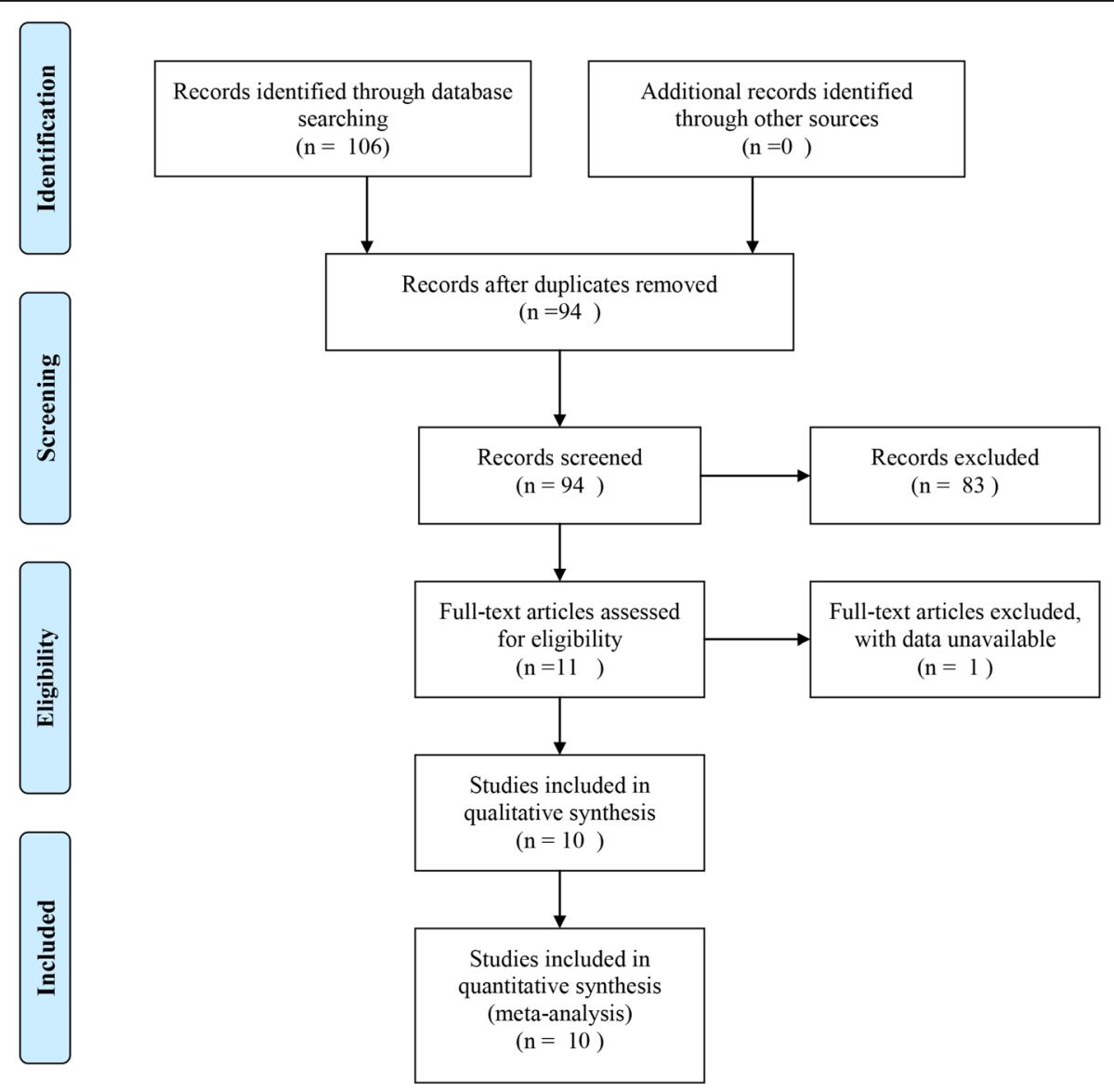

Fig. 1 Flowchart of the study selection process for meta-analysis 
Table 2 Newcastle-Ottawa quality assessment of the included studies

\begin{tabular}{|c|c|c|c|c|c|c|c|c|c|}
\hline \multirow[t]{2}{*}{ Study } & \multicolumn{4}{|l|}{ Selection } & \multirow[t]{2}{*}{ Comparability } & \multicolumn{3}{|l|}{ Outcome } & \multirow[t]{2}{*}{ Scores } \\
\hline & $\begin{array}{l}\text { Representativeness } \\
\text { of the exposed } \\
\text { cohort }\end{array}$ & $\begin{array}{l}\text { Selection of } \\
\text { the non- } \\
\text { exposed } \\
\text { cohort }\end{array}$ & $\begin{array}{l}\text { Ascertainment } \\
\text { of exposure }\end{array}$ & $\begin{array}{l}\text { Outcome of } \\
\text { interest was } \\
\text { presented }\end{array}$ & & $\begin{array}{l}\text { Assessment } \\
\text { of outcome }\end{array}$ & $\begin{array}{l}\text { Follow-up long } \\
\text { enough for } \\
\text { outcomes to } \\
\text { occur }\end{array}$ & $\begin{array}{l}\text { Adequacy } \\
\text { of follow-up } \\
\text { of cohorts }\end{array}$ & \\
\hline $\begin{array}{l}\text { Kawakami } \\
\text { et al. [10] }\end{array}$ & $\star$ & $\star$ & $\star$ & $\star$ & $\star$ & $\star$ & $\star$ & $\star$ & 8 \\
\hline $\begin{array}{l}\text { Hwang et } \\
\text { al. [19] }\end{array}$ & $\star$ & $\star$ & $\star$ & $\star$ & $\star$ & $\star$ & $\star$ & & 7 \\
\hline $\begin{array}{l}\text { Murakami } \\
\text { et al. [11] }\end{array}$ & $\star$ & $\star$ & $\star$ & & $\star$ & $\star$ & $\star$ & $\star$ & 7 \\
\hline $\begin{array}{l}\text { Hirano et } \\
\text { al. [12] }\end{array}$ & $\star$ & $\star$ & $\star$ & $\star$ & $\star$ & & $\star$ & $\star$ & 7 \\
\hline $\begin{array}{l}\text { Komaya et } \\
\text { al. [13] }\end{array}$ & $\star$ & $\star$ & $\star$ & & $\star \star$ & $\star$ & $\star$ & $\star$ & 8 \\
\hline $\begin{array}{l}\text { Uemura et } \\
\text { al. [14] }\end{array}$ & $\star$ & $\star$ & $\star$ & & $\star \star$ & $\star$ & $\star$ & $\star$ & 8 \\
\hline $\begin{array}{l}\text { Wiggers } \\
\text { et al. [18] }\end{array}$ & $\star$ & & $\star$ & $\star$ & & $\star$ & $\star$ & $\star$ & 6 \\
\hline $\begin{array}{l}\text { Komaya et } \\
\text { al. [15] }\end{array}$ & $\star$ & $\star$ & $\star$ & $\star$ & $\star \star$ & $\star$ & $\star$ & $\star$ & 9 \\
\hline $\begin{array}{l}\text { Higuchi et } \\
\text { al. [16] }\end{array}$ & $\star$ & $\star$ & $\star$ & $\star$ & $\star \star$ & $\star$ & $\star$ & $\star$ & 9 \\
\hline $\begin{array}{l}\text { Miura et } \\
\text { al. [17] }\end{array}$ & $\star$ & $\star$ & $\star$ & & $\star$ & $\star$ & $\star$ & $\star$ & 7 \\
\hline
\end{tabular}

${ }^{\star}$ Score of the paper got after assessment

MBO [23, 24], but it still remains controversial whether patients with resectable $\mathrm{MBO}$ would be benefited from PBD [2-4]. Furthermore, whether either PTBD or EBD is better is another puzzle [5-9], although both have been conducted prevalently worldwide. Short-term outcomes, such as pancreatitis, bile leakage, and clinical and technique success rates, are the common indicators to compare the efficacy and safety between PTBD and EBD. From this aspect, EBD has been confirmed superior to PTBD by several meta-analyses [25-27]. Long-term outcome of PBD was rarely taken into consideration of the strategy for patients with $\mathrm{MBO}$, but the superiority of EBD in the overall survival was reconfirmed in our previous meta-analysis [28].

SM is rarely reported globally, but it was reported as high as 4.0 40.4\% in Japan [10-17]. Reasons are as follows: (a) preoperative PTBD longer than 60 days was associated with an increased risk of the SM [29], (b) repeated attempts at PTBD $[29,30]$, and (c) multiple

\begin{tabular}{|c|c|c|c|c|c|c|c|c|c|c|}
\hline Study or Subgroup & $\begin{array}{l}\text { EBD } \\
\text { Events } \\
\end{array}$ & Total & $\begin{array}{l}\text { PTBL } \\
\text { Events }\end{array}$ & Dotal & Weight & $\begin{array}{l}\text { Odds Ratio } \\
\text { M-H, Random, } 95 \% \mathrm{Cl}\end{array}$ & & $\begin{array}{r}\text { Odds } \\
\text { M-H, Rand }\end{array}$ & $\begin{array}{l}\text { s Ratio } \\
\text { dom. } 95 \% \mathrm{Cl}\end{array}$ & \\
\hline Higuchi 2017 & 11 & 76 & 31 & 87 & $13.0 \%$ & $0.31[0.14,0.66]$ & & & & \\
\hline Hirano 2014 & 3 & 74 & 20 & 67 & $7.4 \%$ & $0.10[0.03,0.35]$ & & & & \\
\hline Hwang 2012 & 0 & 122 & 7 & 231 & $2.0 \%$ & $0.12[0.01,2.16]$ & 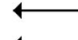 & & & \\
\hline Kawakami 2011 & 0 & 80 & 3 & 48 & $1.8 \%$ & $0.08[0.00,1.60]$ & & & & \\
\hline Komaya 2016 & 13 & 187 & 38 & 189 & $14.7 \%$ & $0.30[0.15,0.58]$ & & & & \\
\hline Komaya 2017 & 25 & 150 & 45 & 165 & $16.6 \%$ & $0.53[0.31,0.92]$ & & - & & \\
\hline Miura 2017 & 2 & 63 & 1 & 25 & $2.6 \%$ & $0.79[0.07,9.09]$ & & & & \\
\hline Murakami 2015 & 12 & 73 & 8 & 20 & $9.1 \%$ & $0.30[0.10,0.88]$ & & & & \\
\hline Uemura 2015 & 63 & 407 & 67 & 166 & $19.0 \%$ & $0.27[0.18,0.41]$ & & & & \\
\hline Wiggers 2015 & 25 & 147 & 14 & 87 & $13.9 \%$ & $1.07[0.52,2.19]$ & & & & \\
\hline Total $(95 \% \mathrm{Cl})$ & & 1379 & & 1085 & $100.0 \%$ & $0.35[0.23,0.53]$ & & & & \\
\hline Total events & 154 & & 234 & & & & & & & \\
\hline \multicolumn{6}{|c|}{$\begin{array}{l}\text { Heterogeneity: } \mathrm{Tau}^{2}=0.20 ; \mathrm{Ch}^{2}=19.20, \mathrm{df}=9(\mathrm{P}=0.02) ; \mathrm{I}^{2}=53 \% \\
\text { Test for overall effect: } Z=4.91(\mathrm{P}<0.00001)\end{array}$} & & 0.01 & $\begin{array}{l}0.1 \\
\text { Favours [EBD] }\end{array}$ & $\begin{array}{cc}1 & 10 \\
& \end{array}$ & 100 \\
\hline
\end{tabular}




\begin{tabular}{|c|c|c|c|c|c|c|c|c|c|c|}
\hline \multirow{2}{*}{$\begin{array}{c}\text { Study or Subgroup } \\
\text { A Peritonea }\end{array}$} & \multicolumn{2}{|c|}{$\begin{array}{l}\text { EBD } \\
\text { Events Total }\end{array}$} & \multicolumn{2}{|c|}{ PTBD } & Weight & \multirow[t]{2}{*}{$\begin{array}{l}\text { Odds Ratio } \\
\text { M-H. Random. } 95 \% \mathrm{Cl}\end{array}$} & \multicolumn{4}{|c|}{$\begin{array}{c}\text { Odds Ratio } \\
\text { M-H. Random. } 95 \% \mathrm{Cl}\end{array}$} \\
\hline & & & & & & & & & & \\
\hline Hirano 2014 & 3 & 74 & 17 & 64 & $6.9 \%$ & $0.12[0.03,0.42]$ & & & & \\
\hline Komaya 2016 & 13 & 187 & 25 & 189 & $12.8 \%$ & $0.49[0.24,0.99]$ & & & & \\
\hline Komaya 2017 & 24 & 150 & 39 & 165 & $14.7 \%$ & $0.62[0.35,1.08]$ & & & & \\
\hline Miura 2017 & 2 & 63 & 1 & 25 & $2.5 \%$ & $0.79[0.07,9.09]$ & & & & \\
\hline Murakami 2015 & 12 & 73 & 8 & 20 & $8.5 \%$ & $0.30[0.10,0.88]$ & & & & \\
\hline Uemura 2015 & 41 & 407 & 37 & 166 & $15.8 \%$ & $0.39[0.24,0.64]$ & & & & \\
\hline \multirow{2}{*}{$\begin{array}{l}\text { Wiggers } 2015 \\
\text { Subtotal }(95 \% \mathrm{Cl})\end{array}$} & 21 & 147 & 11 & 87 & $11.8 \%$ & $1.15[0.53,2.52]$ & & & & \\
\hline & & 1101 & & 716 & $73.1 \%$ & $0.47[0.31,0.74]$ & & & & \\
\hline Total events & 116 & & 138 & & & & & & & \\
\hline \multirow{2}{*}{\multicolumn{11}{|c|}{$\begin{array}{l}\text { Heterogeneity: } \mathrm{Tau}^{2}=0.15 ; \mathrm{Chi}^{2}=11.82, \mathrm{df}=6(P=0.07) ; \mathrm{I}^{2}=49 \% \\
\text { Test for overall effect: } \mathrm{Z}=3.34(\mathrm{P}=0.0008)\end{array}$}} \\
\hline & & & & & & & & & & \\
\hline \multicolumn{11}{|c|}{ B Tube related SM } \\
\hline Hirano 2014 & 0 & 74 & 3 & 167 & $1.8 \%$ & $0.32[0.02,6.18]$ & & & & \\
\hline Hwang 2012 & 0 & 122 & 7 & 231 & $1.9 \%$ & $0.12[0.01,2.16]$ & 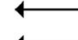 & & & \\
\hline Kawakami 2011 & 0 & 80 & 7 & 48 & $1.9 \%$ & $0.03[0.00,0.62]$ & & & & \\
\hline Komaya 2016 & 0 & 187 & 13 & 189 & $2.0 \%$ & $0.03[0.00,0.59]$ & $\leftarrow$ & & & \\
\hline Komaya 2017 & 1 & 150 & 6 & 165 & $3.2 \%$ & $0.18[0.02,1.49]$ & & & & \\
\hline Miura 2017 & 0 & 63 & 0 & 25 & & Not estimable & & & & \\
\hline Uemura 2015 & 21 & 407 & 30 & 166 & $14.4 \%$ & $0.25[0.14,0.45]$ & & & & \\
\hline \multirow{2}{*}{$\begin{array}{l}\text { Wiggers } 2015 \\
\text { Subtotal }(95 \% \mathrm{CI})\end{array}$} & 0 & 147 & 3 & 87 & $1.8 \%$ & $0.08[0.00,1.60]$ & & & & \\
\hline & & 1230 & & 1078 & $26.9 \%$ & $0.20[0.12,0.34]$ & & & & \\
\hline Total events & 22 & & 69 & & & & & & & \\
\hline \multicolumn{11}{|c|}{ Heterogeneity: $\mathrm{Tau}^{2}=0.00 ; \mathrm{Chi}^{2}=4.45, \mathrm{df}=6(\mathrm{P}=0.62) ; \mathrm{I}^{2}=0 \%$} \\
\hline \multicolumn{11}{|c|}{ Test for overall effect: $Z=6.01(P<0.00001)$} \\
\hline Total $(95 \% \mathrm{Cl})$ & & 2331 & & 1794 & $100.0 \%$ & $0.35[0.23,0.53]$ & & & & \\
\hline Total events & 138 & & 207 & & & & & & & \\
\hline Heterogeneity: $\mathrm{Tau}^{2}=$ & $0.22 ; \mathrm{Chi}^{2}$ & $=24.6$ & $4, \mathrm{df}=13$ & $(P=0$ & $.03) ;\left.\right|^{2}=4$ & $7 \%$ & 0.01 & 0.1 & 10 & 100 \\
\hline $\begin{array}{l}\text { Test for overall effect } \\
\text { Test for subaroun diff }\end{array}$ & $\begin{array}{l}Z=4.92(\mathrm{~F} \\
\text { rences: } \mathrm{Cr}\end{array}$ & $\begin{array}{l}2<0.0 \\
\mathrm{hi}^{2}=6 .\end{array}$ & $\begin{array}{l}\text { D001) } \\
\text { 33. } d f=1\end{array}$ & $(P=0$. & .01). $\left.\right|^{2}=8$ & $3.4 \%$ & 0.01 & Favours [EBD] & Favours [PTBD] & 100 \\
\hline Fig. 3 Subgroup analysi & of (a) peri & toneal & metastasi & $s$ and $(t$ & b) tube-re & ated seeding metastasis & & & & \\
\hline
\end{tabular}

plastic stents were used rather than single one $[29,30]$. In this study, eight included studies came from Japan [10-17], and the total incidence of SM (18.4\%) was higher than that from Korea [19] (2.0\%) and comparable with Netherland-USA [18] (16.7\%). In the view of statistical data, SM was no longer an incident. Hence, the issue of SM deserved much more attention in clinical.

Theoretically, EBD is unlikely to cause SM. In this study, the incidence of SM is much lower in the EBD group than that in the PTBD group $(10.5 \%$ vs. $22.0 \%, P<0.001)$. Potential mechanism of increased PTBD-related SM lied in that as follows: (1) tumor cells derived from the PTBD fluid drainage were reported to be more than those from the EBD [19], which indicated that PTBD was much more likely to cause tumor diffusion. (2) PTBD was performed conventionally in the right liver, where the liver, peritoneum, diaphragm, pleura, and subcutaneous tissue were very close to each other anatomically [17], which offered an appropriate environment for SM. Hence, Takahashi et al. [29] recommended that PTBD should be performed in the left. (3) The general condition was usually much poorer in the patient intended to conduct PTBD, which meant a higher risk for SM.
The location of the MBO might be taken into consideration to decide an appropriate $\mathrm{PBD}$. The recommended level of PTBD is higher than that of EBD for PHC according to the Chinese guideline (IIA vs. IIB) [31], but it remains controversial for DCC and PC in most of the guidelines $[5,6,8]$. In this study, the incidences of SM differed significantly among PHC, DCC, and PC (16.2\% vs. $11.6 \%$, and $22.5 \%)$, partly owing to varied aggressive characteristics of different cancers. However, subgroup analyses which were stratified by PHC, DCC, and PHC showed that the incidences of SM were lower in the EBD groups than those in the PTBD groups $(7.8 \%$ vs. $11.7 \%, P<0.001 ; 6.0 \%$ vs. $18.2 \%, P<$ 0.001 ; $15.6 \%$ vs. $40.3 \%, P<0.001$; respectively), which indicated that EBD was superior to PTBD in the prevention of SM regardless of the location of MBO.

However, we felt puzzled for the mechanism of SM caused by EBD. Technically, EBD was unlikely to cause peritoneal metastasis unless intestinal perforation occurred in the procedure of EBD, especially in the experienced centers. In this study, the overall incidence of tube-related SM in the EBD group is $2.0 \%$. Theoretically, 


\begin{tabular}{|c|c|c|c|c|c|c|c|c|c|c|}
\hline Study or Subgroup & $\begin{array}{l}\text { EBD } \\
\text { Events }\end{array}$ & Total & $\begin{array}{l}\text { PTBD } \\
\text { Events }\end{array}$ & Total & Weight & $\begin{array}{l}\text { Odds Ratio } \\
\text { M-H, Random, } 95 \% \mathrm{Cl}\end{array}$ & & $\begin{array}{r}\text { Odds } \\
\text { M-H, Rand }\end{array}$ & $\begin{array}{l}\text { s Ratio } \\
\text { dom. } 95 \% \mathrm{Cl}\end{array}$ & \\
\hline A $\mathrm{PHC}$ & & & & & & & & & & \\
\hline Higuchi 2017 & 11 & 76 & 31 & 87 & $13.0 \%$ & $0.31[0.14,0.66]$ & & & & \\
\hline Hirano 2014 & 3 & 74 & 20 & 67 & $7.4 \%$ & $0.10[0.03,0.35]$ & & & & \\
\hline Hwang 2012 & 0 & 122 & 7 & 231 & $2.0 \%$ & $0.12[0.01,2.16]$ & & & & \\
\hline Kawakami 2011 & 0 & 80 & 3 & 48 & $1.8 \%$ & $0.08[0.00,1.60]$ & $\vdash$ & & & \\
\hline Komaya 2017 & 25 & 150 & 45 & 165 & $16.6 \%$ & $0.53[0.31,0.92]$ & & & & \\
\hline Wiggers 2015 & 25 & 147 & 14 & 87 & $13.9 \%$ & $1.07[0.52,2.19]$ & & & & \\
\hline Subtotal $(95 \% \mathrm{Cl})$ & & 649 & & 685 & $54.7 \%$ & $0.35[0.17,0.74]$ & & & & \\
\hline Total events & 64 & & 120 & & & & & & & \\
\hline \multicolumn{11}{|c|}{$\begin{array}{l}\text { Heterogeneity: } \mathrm{Tau}^{2}=0.46 ; \mathrm{Chi}^{2}=14.60, \mathrm{df}=5(\mathrm{P}=0.01) ; \mathrm{I}^{2}=66 \% \\
\text { Test for overall effect: } Z=2.76(\mathrm{P}=0.006)\end{array}$} \\
\hline \multicolumn{11}{|l|}{ B DCC } \\
\hline Komaya 2016 & 13 & 187 & 38 & 189 & $14.7 \%$ & $0.30[0.15,0.58]$ & & & & \\
\hline Miura 2017 & 2 & 63 & 1 & 25 & $2.6 \%$ & $0.79[0.07,9.09]$ & & & & \\
\hline Subtotal $(95 \% \mathrm{CI})$ & & 250 & & 214 & $17.3 \%$ & $0.32[0.17,0.60]$ & & & & \\
\hline Total events & 15 & & 39 & & & & & & & \\
\hline \multicolumn{11}{|c|}{$\begin{array}{l}\text { Heterogeneity: } \mathrm{Tau}^{2}=0.00 ; \mathrm{Chi}^{2}=0.57, \mathrm{df}=1(\mathrm{P}=0.45) ; \mathrm{I}^{2}=0 \% \\
\text { Test for overall effect: } Z=3.50(\mathrm{P}=0.0005)\end{array}$} \\
\hline \multicolumn{11}{|l|}{ C $\mathrm{PC}$} \\
\hline Murakami 2015 & 12 & 73 & 8 & 20 & $9.1 \%$ & $0.30[0.10,0.88]$ & & & & \\
\hline Uemura 2015 & 63 & 407 & 67 & 166 & $19.0 \%$ & $0.27[0.18,0.41]$ & & & & \\
\hline Subtotal $(95 \% \mathrm{Cl})$ & & 480 & & 186 & $28.1 \%$ & $0.27[0.19,0.40]$ & & & & \\
\hline Total events & 75 & & 75 & & & & & & & \\
\hline \multicolumn{11}{|c|}{$\begin{array}{l}\text { Heterogeneity: } \mathrm{Tau}^{2}=0.00 ; \mathrm{Chi}^{2}=0.02, \mathrm{df}=1(\mathrm{P}=0.88) ; \mathrm{I}^{2}=0 \% \\
\text { Test for overall effect: } Z=6.62(\mathrm{P}<0.00001)\end{array}$} \\
\hline Total $(95 \% \mathrm{Cl})$ & & 1379 & & 1085 & $100.0 \%$ & $0.35[0.23,0.53]$ & & & & \\
\hline Total events & 154 & & 234 & & & & & & & \\
\hline $\begin{array}{l}\text { Heterogeneity: } \mathrm{Tau}^{2}= \\
\text { Test for overall effect: } \\
\text { Test for subaroun diffe }\end{array}$ & $\begin{array}{l}0.20 ; \mathrm{Chi}^{2} \\
\mathrm{Z}=4.91(\mathrm{~F} \\
\text { rences: } \mathrm{Cr}\end{array}$ & $\begin{array}{l}=19.2 \\
\partial<0.0 \\
\mathrm{hi}^{2}=0 .\end{array}$ & $\begin{array}{l}0, d f=9(F \\
0001) \\
44 . d f=2\end{array}$ & $\begin{array}{l}P=0.0 \\
(P=0 .\end{array}$ & $\begin{array}{l}02) ; I^{2}=53 \% \\
.80) \cdot I^{2}=0 \%\end{array}$ & & 0.01 & $\begin{array}{l}0.1 \\
\text { Favours [EBD] }\end{array}$ & $\begin{array}{lc}10 & 10 \\
\text { Favours } & {[\mathrm{PTBD}]}\end{array}$ & 100 \\
\hline Fig. 4 Subgroup analysis & of seeding & $g$ metas & stasis rates & derive & ed from $(\mathbf{a})$ & $\mathrm{PHC}$, (b) DCC, and (c) & & & & \\
\hline
\end{tabular}

EBD was unlikely to cause peritoneal SM, because the whole procedure of EBD was conducted inside the biliary duct. In this study, we divided SM into tube-related SM and peritoneal SM, and subgroup analysis showed that both the rate of tube-related SM and peritoneal metastasis decreased significantly in the EBD group $(2.0 \%$ vs. $6.7 \%, P<0.001 ; 10.0 \%$ vs. $20.2 \%, P<0.001$; respectively). Hence, we concluded that EBD was superior to

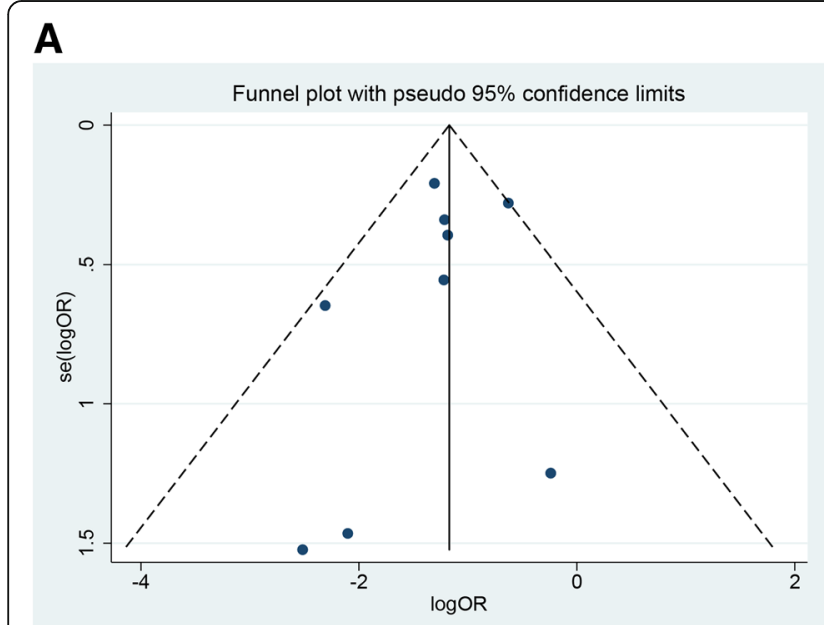

B

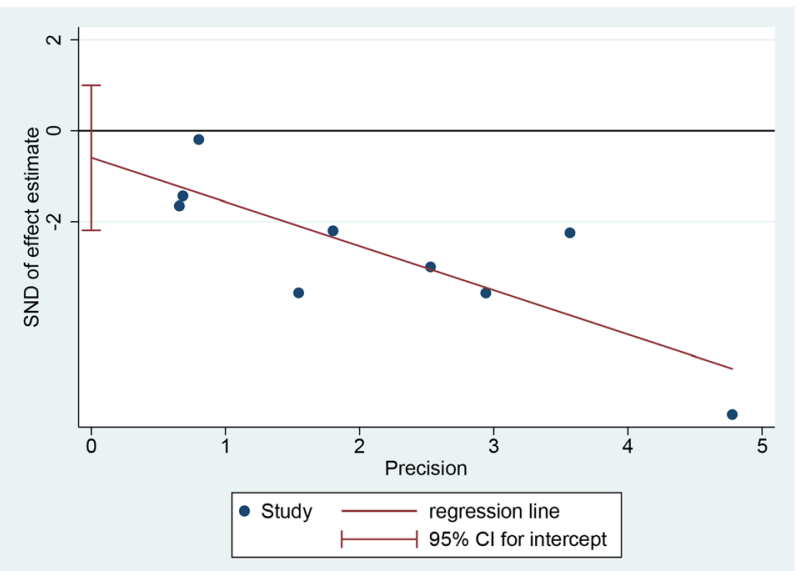

Fig. 5 a, b Publication bias and sensitivity analysis 
PTBD in the prophylaxis of SM, although the definition of SM remained controversial.

There were several limitations in this study. First, there were no RCTs included in this meta-analysis, which made the conclusion sound weaken because cohort data had selection bias. Second, studies included in this meta-analysis were nearly from Japan, which indicated obvious regional bias. Third, PTBD was available when EBD failed, but those patients belonged to which group remained inconsistent $[15,19]$. Bias could be also due to the following: (a) the requirement for an alternative drainage procedure due to therapeutic or technical failures was likely higher in the EBD group compared to patients undergoing preoperative PTBD and (b) Bismuth type III and IV tumors as compared to type I and II tumors were potentially better decompressed percutaneously, especially in the presence of complex strictures. Fourth, the definition of SM varied from each other due to the lack of a golden standard, for example, intrahepatic metastasis belonged to PBD-related seeding metastasis in PC [14], but as for PHC and DCC, it tended to be rich in contradiction. Fifth, technical parameters of either PTBD or EBD, such as the procedure of PBD and the stent material, were different from each center, which indicated an inevitable heterogeneity and weaken the reliability. Sixth, the severity of obstructive jaundice, i.e., the level of preoperative serum bilirubin, was far from consistency, and caution should be taken when interpreting these results. The last but not the least, it was hard to avoid publication bias, because the journals tend to publish positive results.

In summary, we concluded that EBD was superior to PTBD for resectable MBO in the prophylaxis of SM, but there were currently not enough evidences. In the future, working out the definition of SM related to PBD is the urgent affair.

\section{Acknowledgements \\ The abstract of this manuscript was published on the 12th ILCA Annual Conference (https://www.ilca2018.org/wp-content/uploads/2018/08/ILCA- 2018-Final-Programme-and-Book-of-Abstracts_LR_compressed-2.pdf).}

\section{Authors' contributions}

LW contributed to the acquisition of the data, analysis and interpretation of the data, drafting of the article, and final approval. NL and FX contributed to the acquisition of the data, analysis and interpretation of the data, and drafting of the article. $Y Z$ contributed to the conception and design of the study, revision of the article, and final approval. JL contributed to the conception and design of the study, critical revision, and final approval. All authors read and approved the final manuscript.

\section{Funding}

Wu Jieping Medical Foundation (LDWJPMF-102-17007)

\section{Availability of data and materials}

All data generated or analyzed during this study are included in the published articles.

Ethics approval and consent to participate Not applicable
Consent for publication

Not applicable

\section{Competing interests}

The authors declare that they have no competing interests.

\section{Author details}

${ }^{1}$ The United Innovation of Mengchao Hepatobiliary Technology Key Laboratory of Fujian Province, Mengchao Hepatobiliary Hospital of Fujian Medical University, Fuzhou 350025, Fujian, People's Republic of China. ${ }^{2}$ The Liver Center of Fujian Province, Fujian Medical University, Fuzhou 350025, Fujian, People's Republic of China. ${ }^{3}$ The First Clinical Medical College of Fujian Medical University, Fuzhou 350005, Fujian, People's Republic of China. ${ }^{4}$ Liver Disease Center, The First Affiliated Hospital of Fujian Medical University, Fuzhou 350007, Fujian, People's Republic of China. ${ }^{5}$ Mengchao Hepatobiliary Hospital of Fujian Medical University, Xihong Road 312, Fuzhou 350025, Fujian, People's Republic of China.

Received: 10 February 2019 Accepted: 20 June 2019

Published online: 05 July 2019

\section{References}

1. Nagino $M$, Ebata $T$, Yokoyama $Y$, Igami $T$, Sugawara $G$, Takahashi $Y$, Nimura $Y$. Evolution of surgical treatment for perihilar cholangiocarcinoma: a single-center 34-year review of 574 consecutive resections. Ann Surg. 2013;258:129.

2. CI AR, T C LB, A V AG. Role of preoperative biliary drainage in jaundiced patients who are candidates for pancreatoduodenectomy or hepatic resection. Ann Surg. 2013;257:191.

3. Fang Y, Gurusamy KS, Wang Q, Davidson BR, Lin H, Xie X, Wang C. Meta-analysis of randomized clinical trials on safety and efficacy of biliary drainage before surgery for obstructive jaundice. Brit J Surg. 2013;100:1589-96.

4. Umeda J, Itoi T. Current status of preoperative biliary drainage. J Gastroenterol. 2015;50:940-54.

5. Banales JM, Cardinale V, Carpino G, Marzioni M, Andersen JB, Invernizzi $P$, Lind GE, Folseraas T, Forbes SJ, Fouassier L, et al. Expert consensus document: cholangiocarcinoma: current knowledge and future perspectives consensus statement from the European Network for the Study of Cholangiocarcinoma (ENS-CCA). Nat Rev Gastroenterol Hepatol. 2016;13:261-80

6. Tempero MA, Malafa MP, Alhawary M, Asbun H, Bain A, Behrman SW, Rd BA, Binder E, Cardin DB, Cha C. Pancreatic adenocarcinoma, version 2.2017, NCCN Clinical Practice Guidelines in Oncology. J Natl Compr Canc Netw. 2017;15:1028.

7. Rerknimitr $R$, Angsuwatcharakon P, Ratanachu-ek T, Khor CJ, Ponnudurai R, Moon JH, Seo DW, Pantongrag-Brown L, Sangchan A, Pisespongsa P, et al. Asia-Pacific consensus recommendations for endoscopic and interventional management of hilar cholangiocarcinoma. J Gastroenterol Hepatol. 2013;28:593-607.

8. Yamaguchi K, Okusaka T, Shimizu K, Furuse J, Ito Y, Hanada K, Shimosegawa T, Okazaki K. Clinical practice guidelines for pancreatic cancer 2016 from the Japan Pancreas Society: a synopsis. Pancreas. 2017;46:595-604.

9. Mansour JC, Aloia TA, Crane CH, Heimbach JK, Nagino M, Vauthey JN. Hilar cholangiocarcinoma: expert consensus statement. HPB (Oxford). 2015;17:691-9.

10. Kawakami H, Kuwatani M, Onodera M, Haba S, Eto K, Ehira N, Yamato H, Kudo T, Tanaka E, Hirano S, et al. Endoscopic nasobiliary drainage is the most suitable preoperative biliary drainage method in the management of patients with hilar cholangiocarcinoma. J Gastroenterol. 2011;46:242-8.

11. Murakami Y, Uemura K, Hashimoto Y, Kondo N, Nakagawa N, Sasaki H, Hatano N, Kohmo T, Sueda T. Does preoperative biliary drainage compromise the long-term survival of patients with pancreatic head carcinoma? J Surg Oncol. 2015;111:270-6.

12. Hirano S, Tanaka E, Tsuchikawa T, Matsumoto J, Kawakami H, Nakamura T, Kurashima Y, Ebihara Y, Shichinohe T. Oncological benefit of preoperative endoscopic biliary drainage in patients with hilar cholangiocarcinoma. J Hepatobiliary Pancreat Sci. 2014;21:533-40.

13. Komaya K, Ebata T, Fukami Y, Sakamoto E, Miyake H, Takara D, Wakai K, Nagino M. Percutaneous biliary drainage is oncologically inferior to 
endoscopic drainage: a propensity score matching analysis in resectable distal cholangiocarcinoma. J Gastroenterol. 2016;51:608-19.

14. Uemura K, Murakami Y, Satoi S, Sho M, Motoi F, Kawai M, Matsumoto I, Honda G, Kurata M, Yanagimoto H, et al. Impact of preoperative biliary drainage on long-term survival in resected pancreatic ductal adenocarcinoma: a multicenter observational study. Ann Surg Oncol. 2015; 22(Suppl 3):S1238-46.

15. Komaya K, Ebata T, Yokoyama Y, Igami T, Sugawara G, Mizuno T, Yamaguchi $J$, Nagino M. Verification of the oncologic inferiority of percutaneous biliary drainage to endoscopic drainage: a propensity score matching analysis of resectable perihilar cholangiocarcinoma. Surgery. 2017;161:394-404.

16. Higuchi R, Yazawa T, Uemura S, Izumo W, Chaudhary R, Furukawa T, Yamamoto $M$. ENBD is associated with decreased tumor dissemination compared to PTBD in perihilar cholangiocarcinoma. J Gastrointest Surg. 2017.

17. Miura F, Sano K, Wada K, Shibuya M, Ikeda Y, Takahashi K, Kainuma M, Kawamura S, Hayano K, Takada T. Prognostic impact of type of preoperative biliary drainage in patients with distal cholangiocarcinoma. Am J Surg. 2017; 214:256-61.

18. Wiggers JK, Groot KB, Coelen RJ, Doussot A, van Dieren S, Rauws EA, Schattner MA, van Lienden KP, Brown KT, Besselink MG, et al. Percutaneous preoperative biliary drainage for resectable perihilar cholangiocarcinoma: no association with survival and no increase in seeding metastases. Ann Surg Oncol. 2015;22(Suppl 3):S1156-63.

19. Hwang S, Song GW, Ha TY, Lee YJ, Kim KH, Ahn CS, Sung KB, Ko GY, Kim $\mathrm{MH}$, Lee SK, et al. Reappraisal of percutaneous transhepatic biliary drainage tract recurrence after resection of perihilar bile duct cancer. World J Surg. 2012;36:379-85.

20. Deeks JJ, Altman DG. Chapter 9. Analysing data and undertaking metaanalyses. In: Cochrane Handbook for Systematic Reviews of Interventions Cochrane Book; 2011.

21. Sewnath ME, Karsten TM, Prins MH, Rauws EJA, Obertop H, Gouma DJ: A meta-analysis on the efficacy of preoperative biliary drainage for tumors causing obstructive jaundice., vol. 236. pp. 17-27; 2002:17-27.

22. Aly EAH, Johnson CD. Preoperative biliary drainage before resection in obstructive jaundice. Digest Surg. 2001;18:84-9.

23. Shim DJ, Gwon DI, Han K, Kim Y, Ko G, Shin JH, Ko HK, Kim JH, Kim JW, Yoon $H$, Sung K. Percutaneous metallic stent placement for palliative management of malignant biliary hilar obstruction. Korean J Radiol. 2018;19:597.

24. Sakai Y, Iwai T, Shimura K, Gon K, Koizumi K, ljima M, Chiba K, Nakatani S, Sugiyama $\mathrm{H}$, Tsuyuguchi T, et al. Safety and efficacy of metallic stent for unresectable distal malignant biliary obstruction in elderly patients. World J Gastroentero. 2018;24:69-75.

25. Al MA, Menahem B, Fohlen A, Dupont B, Alves A, Launoy G, Lubrano J. Preoperative biliary drainage in patients with resectable perihilar cholangiocarcinoma: is percutaneous transhepatic biliary drainage safer and more effective than endoscopic biliary drainage? A meta-analysis. J Vasc Interv Radiol. 2017;28:576.

26. Celotti A, Solaini L, Montori G, Coccolini F, Tognali D, Baiocchi G. Preoperative biliary drainage in hilar cholangiocarcinoma: systematic review and meta-analysis. Eur J Surg Oncol. 2017:43:1628-35.

27. Duan F, Cui L, Bai Y, Li X, Yan J, Liu X. Comparison of efficacy and complications of endoscopic and percutaneous biliary drainage in malignant obstructive jaundice: a systematic review and meta-analysis. Cancer Imaging. 2017;17:27.

28. Lei W, Nanping L, Fuli X, Yongyi Z, Jingfeng L: Comparison of long-term efficacy between endoscopic and percutaneous biliary drainage for resectable extrahepatic cholangiocarcinoma with biliary obstruction: a systematic review and meta-analysis. Saudi J Gastroenterol. 2019;25(2):81-8.

29. Takahashi Y, Nishio MN, Ebata T, Igami T, Nimura Y. Percutaneous transhepatic biliary drainage catheter tract recurrence in cholangiocarcinoma. Brit J Surg. 2010;97:1860-6.

30. Kawakubo K, Kawakami H, Kuwatani M, Haba S, Kudo T, Taya YA, Kawahata S, Kubota Y, Kubo K, Eto K, et al. Lower incidence of complications in endoscopic nasobiliary drainage for hilar cholangiocarcinoma. World J Gastrointest Endosc. 2016;8:385

31. China Anti-Cancer Association. Guideline for the diagnosis and therapy of hilar cholangiocarcinoma (2015). Chin J Hepatobiliary Surg. 2015;21(8):505-11.

\section{Publisher's Note}

Springer Nature remains neutral with regard to jurisdictional claims in published maps and institutional affiliations.

\section{Ready to submit your research? Choose BMC and benefit from}

- fast, convenient online submission

- thorough peer review by experienced researchers in your field

- rapid publication on acceptance

- support for research data, including large and complex data types

- gold Open Access which fosters wider collaboration and increased citations

- maximum visibility for your research: over $100 \mathrm{M}$ website views per year

At BMC, research is always in progress.

Learn more biomedcentral.com/submissions 